\title{
Job Insecurity and Achievement Motivation of Honorary Teachers
}

\author{
Doddy Hendro Wibowo \\ Fakultas Psikologi Universitas Kristen Satya Wacana \\ doddy.hendro@gmail.com
}

\begin{abstract}
Teacher is a unique job, a job that requires a high commitment beyond the desire for money. This study is for the empirical interest of the relationship between job insecurity and achievement motivation by Honorary Teacher. This study involved 95 teachers with honorary status from 34 educational institutions in kindergarten, elementary / junior high school, high school / vocational school in the suburbs of Salatiga, Central Java. Based on trials with $N=95$ there is no significance of Job Insecurity and Achievement Motivation in Honorary Teachers in Salatiga, Central Java ( $r=0.045 ; p=0.668>0.05 ; 2$-tailed). This means, job insecurity does not give effect to achievement motivation by Honorary Teachers in Salatiga.
\end{abstract}

Keywords: Job Insecurity, Achievement Motivation, Honorary Teacher.

\section{PENDAHULUAN}

Motivasi merupakan komponen penting dan berpengaruh dalam kinerja karyawan. Karyawan yang bermotivasi tinggi adalah orang yang melaksanakan upaya substansial, guna menunjang tujuan-tujuan produksi kesatuan kerjanya dan organisasi di mana ia bekerja, sedangkan karyawan yang bermotivasi rendah, hanya memberikan upaya minimum dalam hal bekerja (Winardi, 2001).

Ada berbagai jenis motivasi yang mempengaruhi kinerja karyawan di dalam organisasi, salah satunya adalah motivasi berprestasi. Teori motivasi yang diungkapkan oleh Abraham Maslow yang melihat bahwa motivasi merupakan suatu keutuhan dari fungsi seseorang (Feist, Feist dan Roberts, 2017). Sedangkan David C. McClelland (dalam Usman, 2006) juga mengungkapkan bahwa manusia memiliki tiga kebutuhan pokok, yaitu: a). kebutuhan akan prestasi (achievement); b) kebutuhan akan kekuasaan (power); dan 3) kebutuhan akan persahabatan (affilition). Siagian (2004) mengungkapkan bahwa seseorang dengan dorongan berprestasi yang tinggi akan menyenangi pekerjaan yang kemungkinan berhasil besar, akan tetapi tidak senang pada tugas yang terlalu berat atau terlalu ringan. Selain itu ia juga tidak senang mengambil resiko besar. Hanya saja dorongan kuat terdapat dalam dirinya untuk secara bertanggung jawab terhadap keberhasilan dan kegagalan melaksanakan tugasnya dan tidak melemparkan tanggung jawab itu kepada orang lain. Nasution (2000) menyebutkan bahwa motivasi berpretasi memiliki fungsi penting, yakni: Menjadi penggerak yang melepaskan energi seseorang, Menentukan arah perbuatan ke tujuan yang akan dicapai, dan menentukan perbuatan-perbuatan apa yang harus dijalankan yang serasi guna mencapai tujuan itu, dengan mengesampingkan perbuatan-perbuatan yang tak bermanfaat bagi tujuan itu.

Motivasi berprestasi merupakan suatu dorongan yang bersumber dari dalam dan luar diri untuk menyelesaikan tugas sebaik-baiknya dan seefektif mungkin hingga mencapai suatu tujuan yang telah ditentukan. Ada berbagai 
macam faktor yang mempengaruhi tingkat motivasi berprestasi seseorang yakni faktor internal dan faktor eksternal. Faktor internal merupakan motivasi yang muncul dari dalam, seperti minat atau keinginan (curiosity), sehingga seseorang tidak lagi termotivasi oleh bentuk-bentuk insentif atau hukuman. Sedangkan motivasi ekstrinsik ialah motivasi yang disebabkan oleh keinginan untuk menerima ganjaran atau menghindari hukuman, motivasi yang terbentuk oleh faktor-faktor eksternal berupa ganjaran dan atau hukuman.

Motivasi berprestasi adalah komponen penting yang dapat meningkatkan kinerja seorang karyawan termasuk pengajar/ guru di dalam organisasi sekolah (Loekmono dan Pobas, 2005). Guru yang memiliki motivasi yang tinggi akan mampu mengemban tugas dan tanggung jawabnya bahkan mampu melampaui target kerja yang ditetapkan. Melalui kinerja guru yang baik dan berprestasi maka visi dan misi di dalam dunia pendidikan dapat dicapai.

Guru di Indonesia, terbagi menjadi dua, yaitu Guru bertatus tetap dan Guru berstatus tidak tetap (Guru honorer). Tugas yang diemban oleh kedua status guru tersebut sama, namun Guru Honorer belum mendapatkan imbalan yang sesuai, Kondisi guru honorer di Indonesia seharusnya mendapatkan perhatian lebih dari pemerintah. Pekerjaan dan tanggung jawab yang diemban tidak sebanding dengan gaji atau perlindungan dan jaminan kesehatan dan jaminan hari tua yang dapat diterima. Pendapatan yang diperoleh berupa honorarium per bulan, cuti dan perlindungan hukum, selain itu mereka tidak mendapatkan fasilitas yang sama dengan guru tetap. Pemberhentian tanpa pesangon juga dapat terjadi karena nasib guru honorer tergantung pada kebijaksanaan kepala sekolah (Balkis dan Masykur, 2016) dan masa depan pekerjaan pun kurang jelas karena status kepegawaiannya (Arfa, Kandou \& Munayang, 2013). Keadaan tersebut membuat guru honorer memiliki perasaan tidak aman berkaitan dengan pekerjaan yang dijalani. Dalam dunia kerja hal ini disebut ketidakamanan kerja (job insecurity).

Ketidakamanan kerja merupakan perhatian individu tentang pekerjaan yang ditekuni (De Witte, 2005). Seorang Guru Honorer yang bekerja di sekolah akan mengalami situasi ketidakamanan kerja di mana ia tidak mengetahui tentang masa depan pekerjaannya (Martinez, De Cuyper, \& De Witte, 2010). Ketidakamanan kerja merupakan suatu antisipasi terhadap ancaman akan adanya risiko berkaitan dengan kelangsungan pekerjaan sehingga menimbulkan perasaan tidak aman di dalam bekerja. Ketidakamanan kerja meliputi dua aspek, yakni aspek kognitif, mengacu pada kemungkinan kehilangan pekerjaan dan aspek afektif, mengacu pada ketakutan kehilangan pekerjaan (Borg\&Eliazur, dalam Sverke, Hellgren,\& Naswall, 2006). Seseorang yang merasa tidak aman atau merasa mendapatkan ancaman dari pihak tertentu maka akan muncul perasaan takut yang besar (Feist, Feist dan Roberts, 2017).

Sverke, Hellgren, dan Naswal (2006), dalam jangka pendek job insecurity akan berdampak terhadap kepuasan kerja, keterlibatan kerja, komitmen organisasi dan kepercayaan terhadap pemimpin, seperti berkurangnya kepercayaan terhadap pemimpin sehingga berdampak pada kesalahpahaman antara pemimpin dan bawahan dalam hal pendapat. Dalam jangka panjang, ketidakamanan kerja akan berdampak terhadap kesehatan fisik, kesehatan mental, performa kerja, dan intensi pindah kerja (turnover).

Silla, Gracia, dan Peiro (2005), melakukan penelitian tentang ketidakamanan kerja kepada pekerja 
berstatus permanen dan temporer dengan jenis kontrak kerja dan jam kerja (full time-part time). Hasil peneitian disimpulkan bahwa kelompok pekerja dengan status temporer memiliki tingkat job insecurity yang lebih tinggi dibandingkan dengan kelompok pekerja berstatus permanen. Penelitian serupa dilakukan oleh Kuroki (2012) yang melibatkan partisipan buruh manufaktur di Jepang berstatus temporer, Hasil penelitian menunjukkan kelompok buruh dengan status temporer memiliki tingkat ketidakamanan kerja lebih tinggi.

Namun

ketidakamanan pengalaman yang sifatnya subjektif. $J o b$ Insecurity merupakan penilaian subyektif individu tentang adanya ancaman berupa 'ketidakpastian' yang mengarah kepada kondisi kehilangan pekerjaan (DeWitte, 2005). Hal ini berarti tingkat keamanan kerja menjadi rendah atau bahkan tidak merasakan ketidakamanan kerja apabila seseorang bekerja karena alasan sukarela atau tidak ada target yang ingin dicapai. Sebaliknya, seseorang yang memiliki persepsi bahwa di dalam bekerja dia harus mampu memenuhi aspek kognitif dan afektif, seperti karir, masa depan, atau takut akan kehilangan pekerjaan maka taraf ketidakamanan kerja menjadi tinggi.

Guru honorer yang bekerja di kota Salatiga memiliki status yang belum pasti dan dimungkinkan merasakan ketidakpastian yang lain, seperti: gaji yang terbatas, fasilitas yang minim, eksistensi sekolah di masa depan, dan kepastian tentang status pekerjaan. Kondisi ketidakpastian tersebut cenderung menimbulkan perasaan tidak aman bekerja (job insecurity) sebagai guru. Tentu saja hal ini akan mempengaruhi aspek sikap kerja yang dimiliki salah satunya adalah aspek motivasi berprestasi dari Guru Honorer yang bekerja di sekolah tersebut. Ketika seorang Guru Honorer, merasa bahwa keberlangsungan pekerjaannya terancam, maka ia akan melakukan evaluasi terhadap lembaga di tempat ia bekerja. Sedangkan seseorang yang kebutuhan rasa aman dalam bekerja dapat terpenuhi, maka ia termotivasi untuk dapat meningkatkan hierarki kebutuhan berikutnya yaitu penghargaan dan aktualisasi diri. Hal ini diperkuat dengan hasil penelitian dari Bonita dan Nurtjahjanti (2016) yang dilakukan kepada Karyawan tetap PT Nyonya Meneer Semarang menunjukkan bahwa ada hubungan negatif antara $J o b$ Insecurity dengan Motivasi Kerja ( $\mathrm{rxy}=-$ 0,223 ). Hal ini menunjukkan semakin tinggi job insecurity maka motivasi kerja akan semakin menurun.

Peneliti tertarik melakukan penelitian dan kajian untuk menguji secara empiris apakah ada hubungan antara Ketidakamanan Kerja dan Motivasi Berprestasi pada Guru Honorer di Kota Salatiga. Peneliti melihat bahwa profesi sebagai Guru merupakan pekerjaan yang unik, pekerjaan yang mensyaratkan pada komitmen yang tinggi melebihi hasrat untuk sekedar mendapatkan uang/ materi (Ariani, 2015). Selai itu, motivasi berprestasi yang dimiliki seorang guru honorer merupakan motivasi yang bersifat inisiatif, dari dalam diri (intrinsik) dan tidak ada paksaan (Andani dan Sulasminten, 2015). Guru merasa bahwa tugas yang diemban merupakan panggilan jiwa dan bisa disebut dengan hobi/ kegemaran. Guru merasa puas apabila muridya berhasil selesai di jenjang tertent dan dapat melanjutkan ke jenjang yang lebih tinggi. Guru juga merasa senang apabila muridnya memahami penjelasan guru dan mengerjakan tugas/ pekerjaan rumah seseuai yang diperintahkan. Hal ini semakin menguatkan bahwa profesi guru, merupakan profesi unik yang tidak bisa dibandingkan dengan yang lain, bahwa di dalamnya ada faktor minat, 
panggilan jiwa dan komitmen (Ariani, 2015; Wangi dan Anisaa, 2015).

Penelitian ini bertujuan untuk menguji secara empiris hubungan antara Ketidakamanan Kerja dengan Motivasi Berprestasi yang dimiliki oleh Guru Honorer.
METODE

Responden Penelitian. Penelitian ini melibatkan 95 guru berstatus honorer dari 34 instansi pendidikan pada jenjang TK, SD/ MI,SMP, SMA/SMK yang ada di daerah pinggiran Kota Salatiga. Data Demografik subjek penelitian disajikan berikut:

Tabel 1. Data Demografik Subjek Penelitian

\begin{tabular}{llll}
\hline & & Frekuensi & Persentase \\
\hline Tempat Mengajar & PAUD & 8 & $9 \%$ \\
& SD/ Sederajat & 41 & $43 \%$ \\
& SMP/ Sederajat & 20 & $21 \%$ \\
& SMA/Sederajat & 26 & $27 \%$ \\
\hline Jenis Kelamin & Laki-laki & 28 & $29 \%$ \\
& Perempuan & 67 & $71 \%$ \\
\hline Usia & 20-30 tahun & 55 & $58 \%$ \\
& 31-40 tahun & 29 & $31 \%$ \\
& 41-50 tahun & 9 & $4 \%$ \\
& $>50$ tahun & 2 & $2 \%$ \\
\hline Latar Belakang & SMA/SMK & 3 & $1 \%$ \\
Pendidikan & Diploma & 4 & $2 \%$ \\
& Strata 1 & 86 & $91 \%$ \\
& Strata 2 & 2 & $1 \%$ \\
\hline Lama Mengajar & 1-5 tahun & 54 & $57 \%$ \\
& 6-10 tahun & 25 & $26 \%$ \\
& $11-15$ tahun & 8 & $9 \%$ \\
& $16-20$ tahun & 4 & $4 \%$ \\
& $>20$ tahun & 4 & $4 \%$ \\
\hline
\end{tabular}

Mengacu pada tabel tersebut, terlihat jenjang dan jumlah guru adalah pada jenjang TK 8 guru (9\%), SD/ MI 41 guru (43\%), SMP 20 guru (21\%), SMA/SMK 26 guru (27\%) yang ada di daerah pinggiran Kota Salatiga. Ditinjau dari jenis kelamin, guru berjenis kelamin laki-laki ada 28 guru (29\%) dan perempuan 67 guru (71\%). Berdasarkan usia 20-30 tahun ada 55 guru (58\%), usia 31-40 tahun ada 29 guru (31\%), usia 41-50 tahun ada 9 guru (4\%) dan berusia lebih dari 50 tahun ada 2 guru (2\%). Berdasarkan latar belakang pendidikan dari lulusan SMA/ SMK ada 3 guru (1\%), Diploma ada 4 guru (2\%), Strata 1/ S1 ada 86 guru (91\%) dan Strata 2/ S2 ada 2 guru (1\%). Berdasarkan lama mengajar yaitu 1-5 tahun ada 54 guru (57\%), 6-10 tahun ada 25 guru (26\%), $11-15$ tahun ada 8 guru
(9\%), 16-20 tahun ada 4 guru (4\%), dan lebih dari 20 tahun ada 4 guru (4\%).

Penelitian ini menggunakan desain penelitian kuantitatif dengan studi korelasional.

Pengambilan sampel menggunakan teknik purposive sampling, dimana partisipan telah ditentukan oleh peneliti dengan beberapa persyaratan yaitu: guru honorer yang bekerja di Sekolah (TK, SD, SMP, \& SMA Swasta maupun Negeri) yang berada di kota Salatiga.

Angket motivasi berprestasi disusun oleh penulis, dengan acuan aspek-aspek motivasi berprestasi yang dikembangkan oleh Tim Achievement Motivation Training (AMT) Massachuset, berdasarkan teori McClelland (dalam Usman, 2006). reliabilitas Angket Motivasi Berprestasi 
dilakukan menggunakan teknik analisis Alpha Cronbach. Dari hasil perhitungan reliabilitas diperoleh hasil $=0,888$. Angka ini menunjukkan bahwa Angket Motivasi Berprestasi yang digunakan dalam penelitian ini reliabel dengan kategori sangat baik (Azwar, 2013). Dan skala Ketidakamanan Kerja atau Job Insecurity Scale/JIS mengadaptasi dari skala yang dikembangkan oleh Ashford, Lee,\& Bobko (1989). Berdasarkan hasil uji coba, nilai Alpha Cronbach adalah 0,925 ; yang berarti bahwa reliabilitas skala ketidakamanan kerja pada penelitian ini tergolong sangat baik (Azwar, 2013).

Teknik Analisis Data. Penelitian ini dilakukan dengan rancangan studi korelasional. Data yang diperoleh dari sampel populasi penelitian selanjutnya akan diolah dengan menggunakan program komputer Statistic Packages for Social Science (SPSS).

\section{HASIL}

Berdasarkan uji korelasi dengan $\mathrm{N}=95$ didapatkan bahwa nilai koefisien $\mathrm{r}$ $=0,045 ;$ dengan probabilitas 0,668 ( $>>0,05 ;$ 2-tailed), nilai probabilitas yang diperoleh tersebut lebih dari 0,05 , sehingga Ho diterima dan Ha ditolak. Hal ini berarti bahwa tidak terdapat hubungan antara Ketidakamanan Kerja dengan Motivasi Berprestasi pada Guru Honorer di Kota Salatiga.

Selanjutnya data mengenai kategorisasi job insecurity guru pada sekolah-sekolah pinggiran di Salatiga disajikan pada Tabel. 2 berikut ini:

Tabel 2. Kategori Job Insecurity dan Motivasi Berprestasi

\begin{tabular}{lcccc}
\hline Kategori & \multicolumn{2}{c}{ Ketidakmanan Kerja } & \multicolumn{2}{c}{ Motivasi Berprestasi } \\
\cline { 2 - 5 } & Frekuensi & Persentase $(\%)$ & Frekuensi & Persentase (\%) \\
\hline Rendah & 14 & 15 & 11 & 12 \\
Sedang & 64 & 67 & 66 & 69 \\
Tinggi & 17 & 18 & 18 & 19 \\
Total & 95 & 100.0 & 95 & 100.0 \\
\hline
\end{tabular}

Berdasarkan tabel kategori di atas, nampak bahwa mayoritas (67\%) guru honorer yang bekerja di Kota Salatiga memiliki tingkat ketidakamanan kerja yang tergolong sedang. Begitu pula dengan kategorisasi Motivasi Berprestasi pada Guru Honorer di Salatiga, menunjukkan bahwa mayoritas (69\%) guru honorer yang bekerja di sekolah pinggiran kota Salatiga memiliki tingkat motivasi berprestasi yang tergolong sedang.

\section{DISKUSI}

Hasil penelitian menunjukkan kondisi yang berbeda dari penelitian sebelumnya yang dilakukan oleh Bonita dan Nurtjahjanti (2016) yang dilakukan kepada Karyawan tetap PT Nyonya
Meneer Semarang menunjukkan bahwa ada hubungan negatif antara $J o b$ Insecurity dengan Motivasi Kerja ( $\mathrm{rxy}=-$ $0,223)$. Peneliti akan mencoba mengkaji hasil penelitian dengan beberapa pendekatan yang dapat memberikan penjelasan tentang faktor penyebab hasil penelitian yang tidak terbukti.

Berdasarkan data demografik, menunjukkan bahwa tingkat motivasi berprestasi yang dimiliki guru honorer tergolong sedang. Hal ini menunjukkan bahwa dorongan atau niat untuk meraih prestasi yang dimiliki oleh Guru Honorer berkaitan dengan pencapaian prestasi dalam tugasnya sebagai guru cenderung sedang. Tim Achievement Motivation Training (AMT) Massachuset, (dalam Usman, 2006) 
orang yang motivasi berprestasinya tinggi memiliki indikator: 1) Bertanggung jawab atas perbuatannya, mengaitkan diri pada karier atau masa depan; 2) Berusaha mencari umpan balik atas segala perbuatannya, mendengarkan pendapat orang lain; 3) Berani mengambil resiko dengan penuh perhitungan melebihi orang lain; 4) Berusaha melakukan sesuatu secara inovatif dan kreatif, banyak gagasan dan mampu mewujudkan gagasannnya dengan baik; 5) Mampu mengatur waktunya, 6) Bekerja keras dan bangga atas hasil yang telah dicapai.

Ada banyak faktor yang dapat mempengaruhi motivasi yakni motivasi yang berasal dari dalam diri (Intrinsik) dan berasal dari luar diri (Ekstrinsik). Guru Honorer dengan kondisi yang serba terbatas, terutama dengan status honorer yang dimiliki, harapan untuk dapat memiliki motivasi berprestasi yang tinggi belum akan terpenuhi. Sesuai dengan teori motivasi yang diungkapkan oleh Abraham Maslow yang melihat bahwa motivasi merupakan suatu keutuhan dari fungsi seseorang (Feist, Feist dan Roberts, 2017). Seseorang akan meningkat ke jenjang yang lebih tinggi apabila jenjang yang lebih rendah telah dipenuhi. Sementara bagi Guru Honorer, aspek keamanan kerja yang belum terpenuhi, misalnya belum ada jaminan kerja atau jaminan perasaan aman dari adanya PHK, belum ada jaminan keselamatan kerja, jaminan kesehatan, belum adanya pemberian tunjangan atau pesangon masa pensiun, serta belum adanya perlindungan dalam bekerja. Beberapa hal tersebut yang kemungkinan menyebabkan para Guru Honorer merasakan ketidakamanan kerja, sehingga untuk dapat meningkat ke jenjang yang lebih tinggi (meraih penghargaan dan berprestasi) belum dapat terwujud.

Ketidakamanan kerja merupakan penilaian subyektif individu tentang adanya ancaman berupa 'ketidakpastian' yang mengarah kepada kondisi kehilangan pekerjaan. Faktor penyebab ketidakamanan kerja yaitu: variabel makro (unsur regional/lokasi tempat kerja dan unsur organisasional); variabel posisional/ latar belakang individu yang menentukan posisinya di tempat kerja (usia, lama bekerja, jabatan, dsb) dan variabel corak kepribadian individu (DeWitte, 2005). Berdasarkan dari data demografik, $67 \%$ guru honorer di kota Salatiga memiliki tingkat ketidakamanan kerja yang tergolong sedang. Ketidakamanan kerja merupakan pengalaman yang subyektif. Berdasarkan variabel corak kepribadian individu, Seseorang bisa memberikan makna yang berbeda terhadap arti dari ketidakamanan kerja, misalnya ada seorang guru yang memaknai statusnya sebagai guru honorer merupakan status yang mengancam pekerjaannya sehingga khawatir tidak bisa bertanggung jawab terhadap keluarga. Namun ada pula yang melihat pekerjaan sebagai guru honorer merupakan sebuah pekerjaan yang dilakukan secara sukarela dan memang ingin bekerja tanpa status tetap karena ingin terbebas dari segala bentuk ikatan (Greenhalgh \& Rosenblatt, 1984). Hal ini pun diperkuat dengan hasil penelitian kepada guru honorer oleh Balkis dan Masykur (2016) yang menyatakan bahwa sebagai seorang Guru Honorer, ada perasaan berupa enggan melepas pekerjaan karena telah merasa nyaman, memantapkan diri untuk terus mengabdi dan bertahan terus untuk menjadi seorang guru walaupun tidak ada kejelasan secara status.

Berdasarkan data demografik penelitian, juga terdapat 67 orang guru Honorer berjenis kelamin perempuan (71\%). Apabila ini dikaitkan dengan peran gender di dalam keluarga, seorang perempuan atau istri memiliki peran dan tanggung jawab yang tidak sebesar yang diemban laki-laki atau suami sebagai Kepala Keluarga yang bertugas untuk 
memberi nafkah bagi keluarganya. Lakilaki dalam Budaya Patriarki jawa dipandang sebagai penyedia kebutuhan hidup dan pelindug dalam menghadapi dunia di luar keluarga (Hermawati, 2007). Dari hal ini nampak bahwa faktor tanggung jawab untuk menghidupi keluarga pada perempuan yang menjadi subjek penelitian nampak cenderung kurang berpengaruh terhadap perasaan ketidakamanan kerja yang dirasakan oleh Guru Honorer berjenis kelamin perempuan.

\section{SIMPULAN}

Berdasarkan dari hasil penelitian yang diperoleh, dapat disimpulkan bahwa tidak terdapat hubungan antara Ketidakamanan Kerja dengan Motivasi Berprestasi pada Guru Honorer di Kota Salatiga. Hal yang menjadi kelemahan penelitian ini adalah terbatasnya informasi dari Guru Honorer. Oleh sebab itu, untuk penelitian selanjutnya dengan tema yang serupa, dengan metode penelitian kualtitatif, perlu digali lebih lanjut tentang motif, latar belakang individu (peran gender), lokasi dan corak kepribadian dari seorang Guru berstatus Honorer.

\section{DAFTAR PUSTAKA}

Arfa, R.K.D., Kandou L.F.J., \& Munayang, H. (2013). Perbandingan kejadian dan tingkat depresi guru honorer di Sekolah Dasar Negeri pada empat kecamatan di Kota Kotamobagu Provinsi Sulawesi Utara. Jurnal E-Biomedik(Ebm), 1(1), 733-742.

Ariani, D.S. (2015). Hubungan Antara Dukungan Sosial Rekan Kerja dan Komitmen Karier pada Guru SMA di Kota Salatiga. Jurnal Psikologi Undip 14 (2), 111-117.

Ashford, S. J., Lee, C., \& Bobko, P. (1989). Content, causes, and consequences, of job insecurity: A theory-based measure and subtantive test. Academy of Management Journal, 32(4), 803829.

Azwar, S. (2013). Dasar-dasar psikometri. Yogyakarta: Pustaka Pelajar Offset.

Balkis, A.S.\& Masykur, A.M. (2016). Memahami Subjective WellBeing Guru Honorer Sekolah Dasar Negeri (Sebuah Studi Kualitatif Fenomenologis). Jurnal Empati, 5 (2), 223-228.

Bonita, R.\& Nurtjahjanti, H.(2016). Hubungan Antara Job Insecurity Dengan Motivasi Kerja Pada Karyawan Pt. Nyonya Meneer Semarang. Jurnal Empati 5(3), 549-552.

De Witte, H. (2005). Job insecurity: review of the international literature on definitions, prevalence, antecedents and consequences. SA Journal of Industrial Psychology, 31(4), 1-6.

Feist J., Feist, G.J.,Roberts,T. (2017). Teori Kepribadian jilid 1 dan jilid 2 (Ed.8). NY: McGrawHill

Greenhalgh, L.,\& Rosenblatt, Z. (1984). Job insecurity: Toward conceptual clarity. Academy of Management Review, 9, 438-448.

Kuroki, M. (2012). The deregulation of temporary employment and workers' perceptions of job insecurity. ILR Review, 65(3), 560-577.

Loekmono, L dan Pobas. (2005). Hubungan antara Motivasi Berprestasi dengan Kinerja Guru SD Kecamatan Polen, Timor Tengah Selatan. Satya Widya 
Jurnal Penelitian Pengembangan Kependidikan, 18(2). 152 - 157.

Nasution, S. (2000). Didaktik Asas-asas Mengajar. Jakarta: Bumi Aksara.

Siagian, S. (2004). Teori Motivasi dan Aplikasinya. Jakarta: Rineka Cipta.

Usman, H. (2006). Manajemen Teori, Praktik, dan Riset Pendidikan. Jakarta: Bumi Aksara.

Winardi, J. (2001). Motivasi dan Pemotivasian dalam Manajemen. Jakarta: Rajawali Pers.

Martinez, G., DeCuyper, N., \& DeWitte, H. (2010). Review of the job insecurityliterature: The case of Latin America. Avancesen Psicología Latino Americana/Bogotá (Colombia), 28(2),94-204.

Maulidina, N.R. \& Nurtjahjanti, H. (2016). Hubungan Antara Ketidakamanan Kerja Dengan Psychological Well-Being Pada Karyawan Kontrak Rumah Sakit Islam Sultan Agung Semarang. Jurnal Empati 5(2), 189-194.

Silla, Inmaculada., Gracia, Francisco, J., \&Peiro, Jose Maria. (2005). Job insecurity and health-related outcomes among different types of temporary workers. Economic and Industrial Democracy, 26(1), 89-117.

Sugiyono. (2012). Memahami penelitian kualitatif. Bandung: Alfabeta.

Sverke, M., Hellgren, J., \&Naswall, K. (2006). Jobinsecurity: A literature review. Stockholm: National Insitutefor Working Life.

Wangi E.N.\& Anisaa, F.R. (2015). Subjective Well-Being pada Guru Honorer di SMP Terbuka 27 Bandung. Bandung: Psychology Forum UMM. 